\title{
A Decade of Agriculture Graduates' Employability and Career Pathways
}

\author{
Janelle Wilkes ${ }^{\mathrm{a}}$ and Adrienne Burns ${ }^{\mathrm{b}}$ \\ Corresponding author: Janelle Wilkes (jwilkes2@une.edu.au ) \\ ${ }^{\mathrm{a}}$ School of Environmental and Rural Science, University of New England, Armidale, NSW 2351, Australia \\ ${ }^{\mathrm{b}}$ School of Science and Technology and School of Environmental and Rural Science, University of New \\ England, Armidale, NSW 2351, Australia
}

Keywords: rural science, residential college, threshold learning outcomes

International Journal of Innovation in Science and Mathematics Education, 27(4), 2-13, 2019

Special Issue: Agricultural Education

\begin{abstract}
There is increasing pressure on universities to produce employable graduates. Currently, the University of New England (UNE) has a suite of undergraduate agriculture courses. The project used an evidence based approach which evaluated graduate's employability based on their choice of course and the relevance of Australian Threshold Learning Outcomes (TLOs) for Agriculture, which underpin UNE's agriculture courses. The past decade of UNE agriculture graduates (2005-2016) were invited to participate in an online survey. Of the respondents, 95-100\% agreed each TLO was relevant to their current employment. The initial industries that graduates were employed in after graduation were agronomy, agribusiness and animal sciences. Of all graduates who are currently employed in industry, three quarters had changed employers, with two thirds moving to another agricultural industry since commencing work. Over half of the respondents had engaged in additional study from short courses to PhDs, with about $20 \%$ studying to become vocational, primary or secondary teachers. For many graduates on-campus residential college life was important for developing positive connections in learning, social activities and employment networks which persisted post-graduation. Survey results were used to inform the development of an online career pathway resource for prospective and current students, and information from the TLO survey has been fed back into unit and course reviews.
\end{abstract}

\section{Introduction}

Graduate Threshold Learning Outcomes (TLOs) are nationally approved descriptions of knowledge and skills required for a pass-level graduate. They allow universities to facilitate the implementation of academic standards, inform curriculum design, and help identify marketing opportunities for courses. The Agriculture Learning and Teaching Academic Standards outline the key TLOs, based on the general Science TLOs and multi-disciplinary nature of agriculture (Botwright Acuña, Able, Kelder, Bobbi, Guisard, Bellotti, McDonald, Doyle, Wormell, \& Meinke, 2014). Teaching of agriculture emphasises vocational education together with an applied science and management focus encompassing a wide range of agricultural sub-disciplines including agricultural science, animal science, horticulture, agronomy, viticulture and oenology, agribusiness and agricultural economics. The TLOs therefore incorporate both science and vocational based understanding and skills of agriculture, embracing knowledge of agricultural systems; inquiry and problem solving; communications; and personal and professional responsibility (Botwright Acuña et al., 2014).

Pratley (2008) anticipated a skills shortage in the Australian agriculture industry with 2000 jobs available annually and only 800 graduates. It was anticipated that the TLOs, which were developed through nationwide consultation with industry, graduates and academics, would 
help to address this shortfall through curriculum renewal and skilled graduates (Botwright Acuña et al., 2014). However, Pratley (2015) proposes there has been an underestimation of agriculture completions and full-time employment rates because both agricultural and environmental science courses in Australia are reported together. This was confirmed in the report for 2017 graduates: 'In previous AGS [Australian Graduate Survey] reports, it was shown that while employment figures for the aggregated field were low, the figures for some component fields such as agricultural science and agribusiness were very strong' (GradStats 2018 , p.9). The grouping of agriculture and environmental studies may be leading to students and their mentors not considering a career in agriculture.

The 2018 annual survey of recent graduates has confirmed 'agriculture and forestry' graduates have higher rates of employment than 'environmental studies' graduates and the sector mean. The 2018 Quality Indicators for Learning and Teaching (2019) survey reported 68\% of 'agriculture and environmental studies' graduates were in full time employment within four months of completing their Australian undergraduate degree. However, when separated into study areas $79 \%$ of 'agriculture and forestry' graduates were in full time employment, which is $18 \%$ higher than $61 \%$ for 'environmental studies' graduates and 6\% higher than the $73 \%$ sector mean (Quality Indicators for Learning and Teaching 2019). With more transparent reporting of graduate employment there may be an increase in students studying agriculture; however, salaries are still grouped.

Graduate salaries for agriculture may have also been underestimated due to the grouping with environmental courses. In 2011, bachelor level agriculture and environmental graduates had lower starting incomes compared with non-STEM graduates. More specifically the percentage of bachelor graduates that had an income greater than \$104 000 was $15 \%$ for non-STEM graduates, compared to $11 \%$ of agriculture graduates and $12 \%$ of environmental graduates (Office of the Chief Scientist, 2016). In contrast, Pratley (2015) showed starting salaries for agriculture, in 2012, were in the top 10 graduate salary bracket, compared with the 2012 Graduate Careers Australia survey with agriculture grouped with environmental studies graduates and was ranked $17^{\text {th }}$ of 23 study areas. The 2018 Quality Indicators for Learning and Teaching (2019) survey (formerly administered by Graduate Careers Australia) still combines the study areas for 'agriculture and environmental studies' for salaries. Undergraduate median full time salaries for 'agriculture and environmental studies' graduates in 2018 was $\$ 58$ 300, below that of the median salary of \$61000 across the whole sector and ranked 15 of 21 study areas (Quality Indicators for Learning and Teaching 2019). Although employment status has been somewhat addressed, graduate income remains unclear for the agriculture sector.

\section{Context of UNE}

The University of New England (UNE) is a regional Australian university situated in Armidale, NSW, formed in 1938 as a college of the University of Sydney, becoming fully independent in 1954 and has large-scale on-campus residential colleges. The introduction of the faculties of Rural Science in 1956 and Agricultural Economics in 1958 enabled introduction of their respective four-year bachelor degrees, and expanded the student cohort from a traditional Arts, Science and Economics foundation. Students enrolled from diverse school backgrounds with many from a wider geographical area, a high proportion of mostly male students from country high schools, rural and working-class parents, and first-in-family to attend university. A level of homogeneity occurred in the student cohort based on only four faculties and the student community was isolated and created its own college subculture in the small country town (Beer, 1995). With increasing numbers of students in the late 1950s, the university transformed their 
residences into a large-scale college housing system for the predominantly on-campus residents forming a 'unique experiment in Australian tertiary education' (Beer, 1995, p. 215).

The residential college system is an integral part of the UNE experience with the majority of on-campus first year agriculture students living in college. Over 50000 of UNE's 100000 alumni have called one of the eight colleges home since the first residential college opened in 1957 (UNE 2013). Through college life, students form an ongoing close-knit social network (Harrison, Villano, Lynch, \& Chen, 2015), that potentially continues past graduation.

While the TLOs for agriculture were devised in 2014 (Botwright Acuña et al., 2014), similar principles already formed the basis of all UNE agriculture courses. Lazenby (2011), the Inaugural Professor of Agronomy and later Vice Chancellor of UNE, noted Rural Science rather than 'just' agricultural science at UNE was based on the holistic McClymont model, where agriculture was taught through the ecosystem, based on plant, animal, soil, economic and sociological interactions. This holistic approach rather than a reductionist approach, used by other Australian universities offering agriculture at the time, was beneficial in producing well rounded graduates. At least two other universities in Australia adopted McClymont's approach to course design and this broader rationale resulted in a curriculum providing highly employable Rural Science graduates, in agricultural and other disciplines (Lazenby, 2011). A holistic rationale for curriculum design and the subsequent TLOs have been maintained at UNE in the Bachelor of Rural Science and this philosophy is encompassed in many units shared with the four-year Bachelor of Animal Science, four-year Bachelor of Agriculture/Bachelor of Business; three-year Bachelor of Agriculture, and five-year Bachelor of Agriculture/Bachelor of Laws.

\section{Aims}

This study used an evidence based approach with two aims. The first was to evaluate the employability of agriculture and related graduates at UNE based on relevance of Australian Threshold Learning Outcomes (TLOs) for Agriculture, which underpinned all agriculture courses from 2005 to 2016. The second aim was to use graduate's career pathways to inform the development of an online study and career pathway resource for prospective and current students.

\section{Methods}

Within the School of Environmental and Rural Science, agricultural students form three quarters of the on-campus student cohort; with the majority living in the residential colleges at some time during their study. Most agriculture students study on-campus and the remainder by distance. An anonymous, voluntary online survey was created with drop down menus and open ended questions with ethics approval (UNE HREC Approval Number: HE16-230). The UNE Alumni office sent out 366 invitations to participate in the study to the past decade of UNE agriculture graduates (2005-2016) with valid email addresses. The survey was divided into sections as described in Table 1. 


\section{Table 1. Survey questions}

\section{Background information}

1. From which UNE degree did you graduate?

2. What year did you graduate from your degree?

3 . What was your age when you graduated?

- $18-25,26-35,36-45$, over 45

(age ranges used to ensure anonymity was maintained)

\section{Threshold Learning Outcomes (TLOs)}

4. If you have additional time and would like to help inform how agriculture is taught at UNE into the future, please fill in the table below. Otherwise please scroll to the bottom of this page (Question 6).

5. National standards on what an agriculture graduate requires have been developed and we want to know if our UNE graduates agree with these standards.

The TLOs for agriculture were then given in a table and graduates were asked to rate these as: 'relevant', 'irrelevant' and 'not-applicable'.

\section{Graduate employment}

6. What was your first paid position after graduation relevant to your degree?

- Open-ended

7. In which industry were you employed?

- Drop down menu - agribusiness, agronomy, animal husbandry/welfare, economic/finance, education/training, horticulture; and

- 'other' - where comment could be left.

8. In which location was your employment (Town, State, Country)?

- Open-ended

9. What was the status and name (optional) of your employment?

- Private industry or Public/government industry

- Open-ended for name of employer (optional)

10. What is your current employment status?

- Different to Question 6 (survey went to Question 11)

- Same as Question 6 (survey skipped to Question 14)

11. In which industry are you currently employed? (same as Question 7 above)

12. In which location was your employment (Town, State, Country)? (same as Question 8 above)

13. What was the status and name (optional) of your employment? (same as Question 9 above)

\section{Further study}

14. Are you enrolled in or have you completed any additional study relevant to your career development?

- Yes or No

- If yes

- Course type; Institution name; Sector (University, VET (TAFE), Industry Short Course)

- Please describe if this additional training has improved your career prospects?

\section{Residential colleges}

15. Did you reside in college for all or part of your study?

- Yes or No

- If yes - In which college did you reside?

- Drop down menu of college names

- Did living in college benefit your course progression?

- Yes or No, Please explain

\section{Additional comments}

16. Please provide any comments on the benefits of your degree to your career. 


\section{Results and discussion}

Part 1 threshold learning outcomes had 40 respondents (11\% of participants) and Part 2, 70 respondents (19\% of participants). Similar to the proportion of graduates, the majority of the 70 past students who responded to the questionnaire were 18-25 (92\%) when they graduated, $7 \%$ were $26-45$ with the remainder were over 45 (1\%). From the respondents, $80 \%$ lived oncampus in a residential college.

\section{Threshold Learning Outcomes}

All 40 respondents (11\% of participants) to the TLO section were currently employed; and 95$100 \%$ of respondents agreed that the TLOs were relevant to agricultural graduates (Table 2). This was anticipated as there was extensive industry, student and academic input in TLO development (Botwright Acuña et al., 2014). Those few that found the TLOs were irrelevant were from the combined degree, Bachelor of Agriculture/Bachelor of Laws, and had pursued a legal, rather than an agricultural career. For example, this was highlighted by negative responses to TLO 3. To critically analyse and address dynamic complex problems in agriculture and TLO 2.4. Demonstrating a basic knowledge of economics, business and social science as they apply to agriculture which were agriculture specific. Other negative responses were due to the lack of importance of a specific TLO, for example TLO 4.1: methods of twoway written and verbal communication not being imperative for an occupation as a Labourer, perhaps this was the specific experience in a lack of team work, as other graduates in Labouring roles felt this was relevant.

Australian graduates from 2014 were surveyed again in 2018. Ranked second highest, 41.6\% of 'agricultural and environmental studies' graduates stated they were not fully utilising their skills and education in their current position (Quality Indicators for Learning and Teaching 2018). In contrast, our results demonstrated that the majority of Agriculture graduates, including those no longer in the agriculture industry, found the TLOs were relevant for their future career. Similarly, Palmer, Campbell, Johnson and West (2018) explained only a minority of science bachelor graduates are working in traditional science occupations with the remainder utilising their strong core foundation in science, scientific thinking and transferable skills across the job market.

\section{Graduate employment}

The remaining questions had 70 respondents (19\% of participants) including graduates from Rural Science (28), Agriculture (22), Agriculture/Business (13), Animal Science (Livestock major) or Livestock Science (4) and Agriculture/Laws (3), which is a similar proportion to UNE graduates. Of these 70 respondents, $96 \%$ were employed in the agricultural industry, with their first job after graduation predominantly in the agronomy, agribusiness or animal fields (Figure 1). Similarly, agronomy and animal related production fall within the top 5 'unit group level occupations of agricultural science graduates' of the Office of the Chief Scientist (2016; p.108) survey.

Comparison of first employment and current employment demonstrates movement of graduates between industries once they had workplace experience. Of the respondents, 64 had graduated over a year prior to the survey, of these respondents $75 \%$ changed employers. From our study, some graduates moved away from agronomy and animal based practice towards agribusiness once they had industry experience. Likewise, some moved into education and training or research areas after additional training. The transferable knowledge and skills from their agricultural training and broadness of the agricultural discipline, compared to fields such 
as accounting, were likely to be paramount in their flexibility in further career choice (Palmer et al. 2018).

Table 2. Percentage of respondents $(n=40)$ that agreed the TLOs for agriculture were relevant for agriculture graduates, in brackets industry of graduates that thought the TLO was irrelevant. TLOs extracted from the Agriculture Learning and Teaching Academic Standards (Botwright Acuña et al., 2014)

TLOs for Agriculture

\section{Demonstrate an integrative understanding of agriculture by:}

1.1. Explaining the role and relevance of agriculture and its related sciences, and agribusiness in society.

1.2. Understanding the major biophysical, economic, social and policy drivers that underpin agricultural practice and how they contribute to practice change.

1.3. Understanding how information is adopted and the context within which producers, processors and consumers make decisions

\section{Exhibit depth and breadth of knowledge of agriculture by:}

2.1. Demonstrating knowledge of the core sciences in the context of agriculture.

$97 \%$

2.2. Demonstrating broad generalist knowledge of relevant agricultural production systems and their value chains, with specialist knowledge in at least one area.

2.3. Understanding how knowledge from different sub-disciplines within agriculture is integrated and applied into practice.

2.4. Demonstrating a basic knowledge of economics, business and social science as they apply to agriculture.

\section{Critically analyse and address dynamic complex problems in agriculture by:}

3.1 Identifying contemporary issues and opportunities in agriculture.

$100 \%$

3.2 Gathering, critically evaluating and synthesising information from a range of $97 \%$ relevant sources and disciplines

3.3 Selecting and applying appropriate and/or theoretical techniques or tools in order to conduct an investigation.

3.4 Collecting, accurately recording, analysing, interpreting and reporting data.

Responses

'relevant'

$100 \%$

$100 \%$

$100 \%$

$100 \%$

$100 \%$

$97 \%$

\section{Be effective communicators by:}

4.1 Understanding methods of effective two-way written and verbal $95 \%$ communication with different audiences.

4.2 Communicating with a range of audiences in an agricultural context using a

$97 \%$ variety of modes.

\section{Be accountable for their own learning and professional work by:}

5.1 Being independent and self-directed learners.

5.2 Working effectively, responsibly and safely in an individual and team context.

$97 \%$

5.3 Demonstrating knowledge of the regulatory frameworks relevant to their specialist area in agriculture 


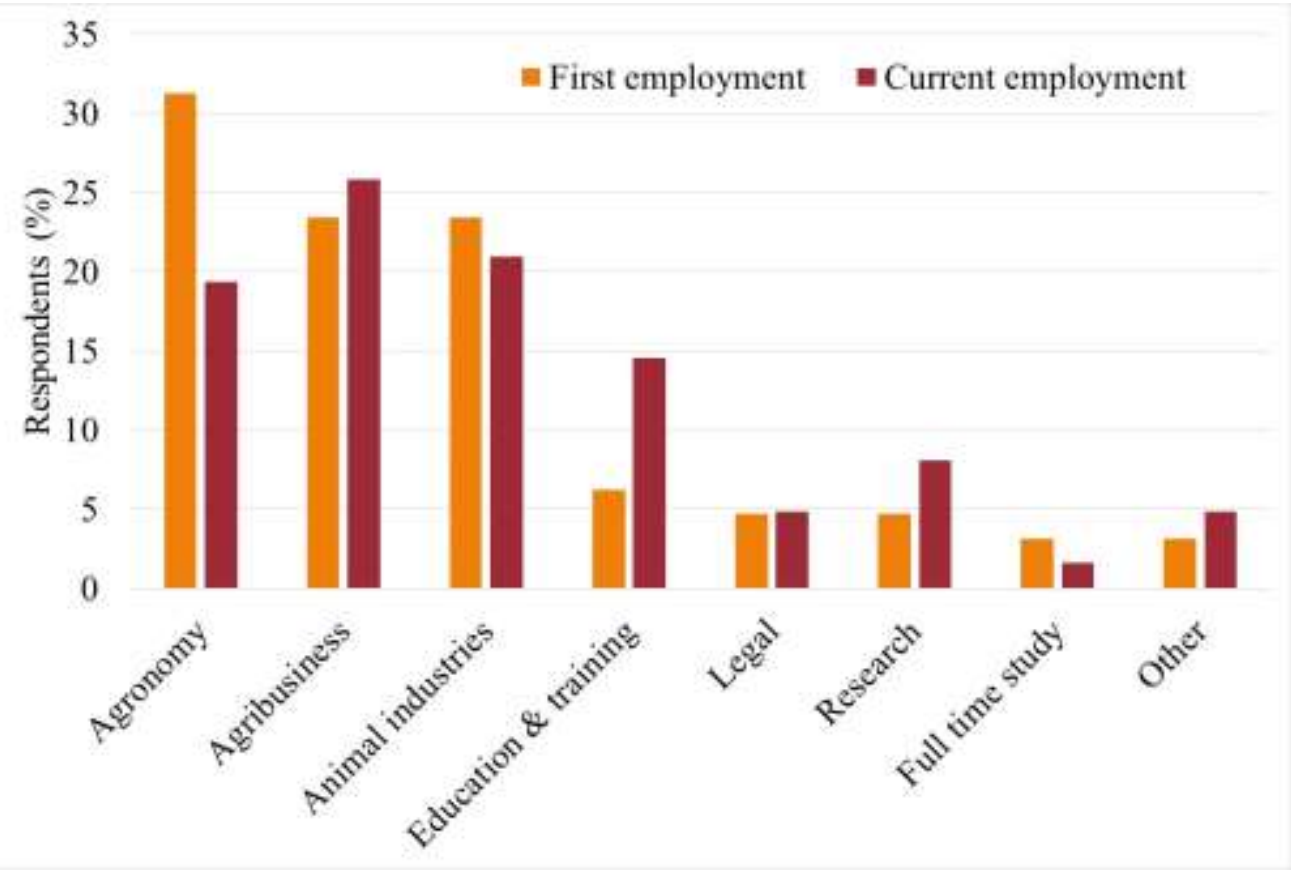

Figure 1: Proportion of respondents $(n=64)$ in each industry, showing first employment, and current employment (for those more than one year since graduation). *

* Agronomic - agronomy, soil science, horticulture and precision agriculture; Agribusiness - finance, marketing, management and sales; Animal industries - animal husbandry, health, welfare, nutrition and biosecurity; Education and training - university, school and vocational education; Research - various agronomic and animal agricultural industries; Other - retired, manufacturing, intelligence analyst

To allow comparisons to the Office of the Chief Scientist (OCS) (2016) report, graduate data of occupation was classified according to the Australian and New Zealand Standard Classification of Occupations (ANZSCO) (Australian Bureau of Statistics 2013). It should be noted the current study was for the past decade of graduates whereas the OCS report included all agriculture graduates identified through the 2006 and 2011 Census of Population and Housing. The OCS report found $31 \%$ of agriculture graduates were employed as Managers (chief executives, managers, farmers and farm managers); however in the current study there were no Managers at graduation but 7\% in later years. It is likely over time the proportion of respondents in managerial roles will increase to correspond with the OCS report. Professional careers were much higher in the current study than the OCS report which reported $31 \%$ of agriculture graduates were employed as Professionals (including business, human resource, marketing, education, science and legal professionals). The current study showed $60 \%$ of graduates were initially employed as Professionals, with an increase to $80 \%$ after one or more years from graduation. Graduates moved from technical and labouring roles to managerial and professional roles (Figure 2). Graduate skills allowed the movement of graduates between occupations. For example, although as expected many graduates from the double degree of Bachelor of Agriculture and Bachelor of Business followed agribusiness careers, due to their broad knowledge the more science based Bachelor of Rural Science also entered the agribusiness sector in the years after their graduation. 


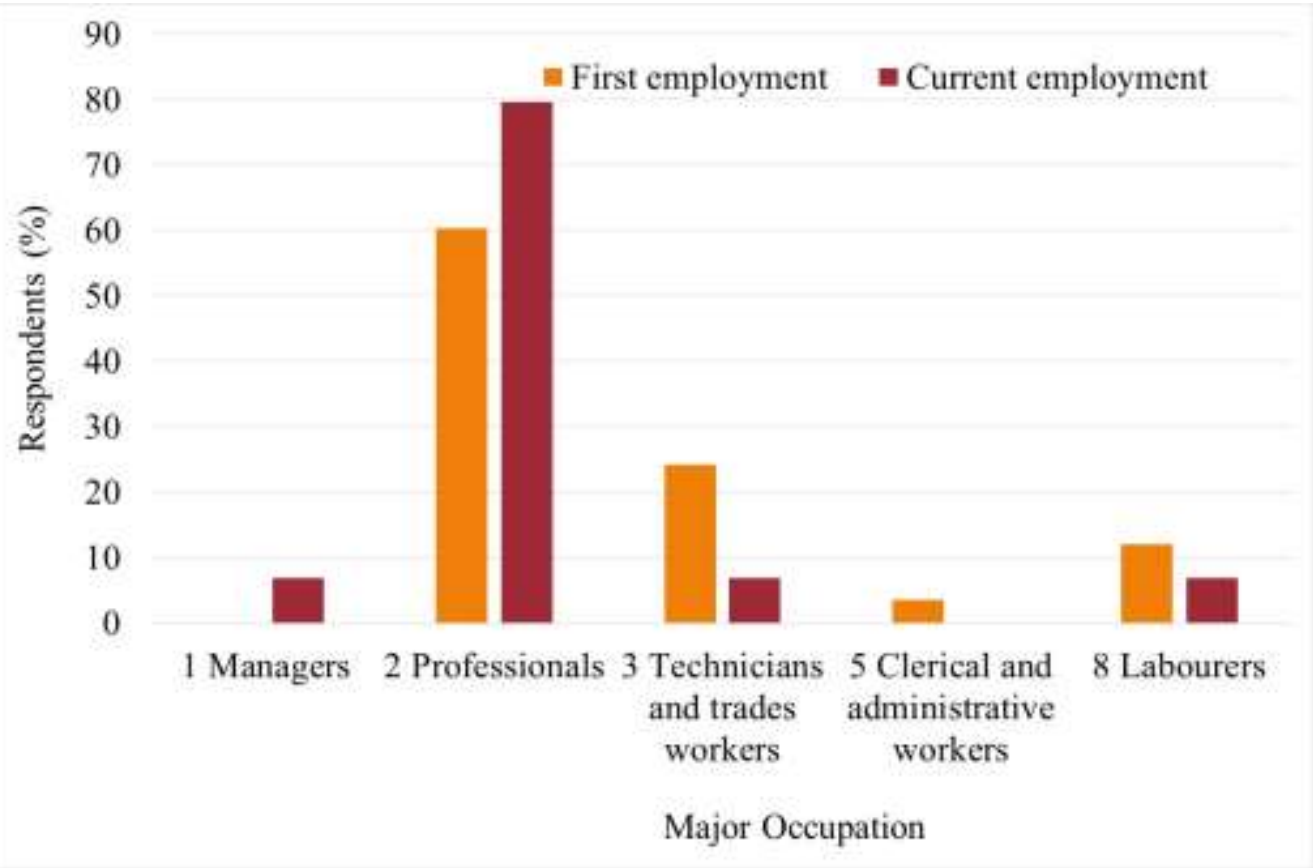

Figure 2: Proportion of respondents ( $n=59)$ working in major occupation (ANZSCO classification), showing first employment, and current employment (for those more than one year since graduation, excluding those in full time study)

\section{Training}

Of the 70 respondents, $54 \%$ were participating in or had completed additional study ranging from short courses through to completion of doctoral studies (Table 3). The reasons for undertaking additional Higher Research ( $\mathrm{PhD}$ and Masters) qualifications included it was a requirement for their higher career position, and provided access to higher paid positions. Course work Masters and Graduate diplomas provided graduates access to teaching positions with $9 \%$ of respondents being secondary school teachers, this is more than the $2 \%$ in the OCS (2016) report. Further bachelor degrees provided opportunities to change career trajectory such as becoming a primary school teacher, or provided specific skill requirements for future employment (Table 3).

A summary of UNE courses and the proportion of respondents undertaking additional study is demonstrated in Table 4. The highest proportion to undertake further study were Bachelor of Agriculture/Laws students, due to the requirement for practical legal training to become a solicitor. Bachelor of Livestock Science graduates undertook further training to become veterinary scientists and $\mathrm{PhDs}$ to become researchers in academic positions. Of the Bachelor of Agriculture graduates, 59\% undertook further study, with $46 \%$ of these graduates undertaking further study to become primary school and secondary science or agriculture teachers. The Bachelor of Agriculture/Business had the fewest graduates undertaking further training, but one graduate became a secondary science and agriculture teacher. Bachelor of Rural Science had $54 \%$ of graduates engage in further training with $27 \%$ undertaking a $\mathrm{PhD}$ and $13 \%$ research masters.

Graduates' first and current employment were $76 \%$ and $73 \%$ private, respectively; and the remainder in the public sector. This result is slightly lower than the Office of the Chief Scientist (2016) which in 2011 found 83\% of bachelor graduates worked in the private sector. Interestingly $47 \%$ of graduates with doctorates were in the private industry (Office of the Chief 
Scientist 2016); similarly in the current study the sample size was small (6 graduates) but $40 \%$ were employed in the private sector. Income was not investigated in the current study, but the OCS (2016) reported for 2011 of the 24000 agricultural science graduates, the proportion of graduates earning more than $\$ 104000$ per annum more than doubles from $11 \%$ with a bachelor degree to $24 \%$ with doctoral qualification.

Table 3: Number of graduates participating in or completed further study and quotes for reasons to undertake further study.

\begin{tabular}{|c|c|c|c|}
\hline $\begin{array}{l}\text { Level of } \\
\text { course }\end{array}$ & $\begin{array}{c}\text { Number } \\
\text { participants }\end{array}$ & Courses & $\begin{array}{l}\text { Quotes of why undertook additional } \\
\text { study }\end{array}$ \\
\hline $\mathrm{PhD}$ & 6 & $\begin{array}{l}\text { Research, veterinary } \\
\text { science }\end{array}$ & $\begin{array}{l}\text { "I would not have secured my current } \\
\text { position without postgraduate } \\
\text { qualifications" }\end{array}$ \\
\hline Masters & 6 & $\begin{array}{l}\text { Agriculture, secondary } \\
\text { teaching, business } \\
\text { administration }\end{array}$ & $\begin{array}{l}\text { "given me opportunity to apply for } \\
\text { higher ranked positions" } \\
\text { "Yes - put me in front of other } \\
\text { candidates when applying for } \\
\text { management positions." }\end{array}$ \\
\hline Grad diploma & 4 & $\begin{array}{l}\text { Secondary teaching, } \\
\text { practical legal training }\end{array}$ & $\begin{array}{l}\text { "I will always have work as a teacher- } \\
\text { there is a significant shortage" }\end{array}$ \\
\hline $\begin{array}{l}\text { Graduate } \\
\text { certificate }\end{array}$ & 4 & Agriculture & $\begin{array}{l}\text { "...improving my knowledge in my } \\
\text { current position and will assist in } \\
\text { advancing my career." }\end{array}$ \\
\hline Bachelor & 4 & $\begin{array}{l}\text { Accounting, primary } \\
\text { teaching }\end{array}$ & "It allowed me to switch industries." \\
\hline Diploma & 2 & Management & $\begin{array}{l}\text { "...assisted in me taking a management } \\
\text { role." }\end{array}$ \\
\hline Certificate & 4 & $\begin{array}{l}\text { Training and assessment } \\
\text { in vocation sector, } \\
\text { welding, }\end{array}$ & $\begin{array}{l}\text { "... access to teach in the VET sector" } \\
\text { "It has allowed me to gain practical } \\
\text { skills within industry that have got me to } \\
\text { where I am at the moment" }\end{array}$ \\
\hline Short course & 8 & $\begin{array}{l}\text { Finance, welfare, } \\
\text { conflict resolution, } \\
\text { human resource } \\
\text { management, animal } \\
\text { management }\end{array}$ & $\begin{array}{l}\text { "The courses I did helped me develop } \\
\text { skills that were vital to my Job." }\end{array}$ \\
\hline Total & 38 & & \\
\hline
\end{tabular}

Table 4: Proportion of respondents who undertook additional training based on their UNE course.

\begin{tabular}{lcc}
\hline UNE Course undertaken & Total respondents & $\begin{array}{c}\text { Number of respondents who undertook } \\
\text { additional training (in brackets \% } \\
\text { respondents from that course) }\end{array}$ \\
\hline B Agriculture & 22 & $13(59 \%)$ \\
B Agriculture/B Business & 13 & $4(31 \%)$ \\
B Agriculture/B Laws & 3 & $3(100 \%)$ \\
B Animal Science or & 4 & $3(75 \%)$ \\
Livestock Science & 28 & $15(54 \%)$ \\
B Rural Science & 70 & $38(54 \%)$ \\
\hline Total & & \\
\hline
\end{tabular}




\section{Location of first and current employment}

In this study three quarters of graduates either lived in Australian capital cities (such as Sydney and Hobart) or country areas including towns (such as Nyngan, Kempsey and Macksville in New South Wales (NSW)) or regional cities (such as Armidale, Dubbo and Bathurst in NSW). The location of graduate's first employment and current employment shows a substantial movement of graduates into country NSW, from $66 \%$ to $76 \%$, respectively (Figure 3 ). Location of employment in country areas in other states also decreased from $15 \%$ to $2 \%$ from first to current employment. Graduates in Sydney and other capital cities remained stable at 10 to $11 \%$ in Sydney and 9 to $11 \%$ in other capital cities.

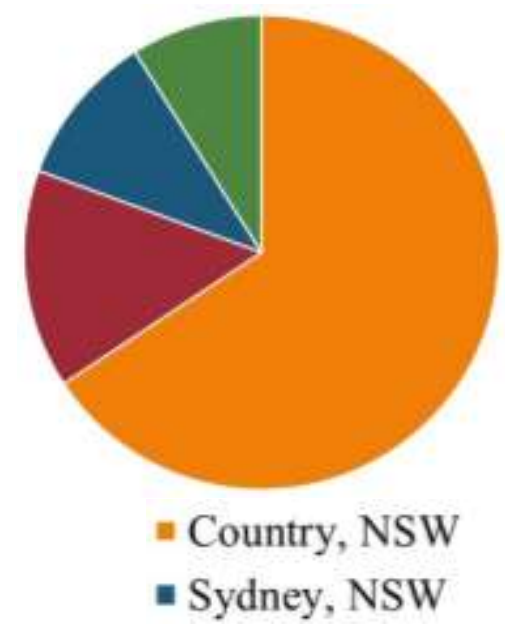

Figure 3: a. Location of first employment

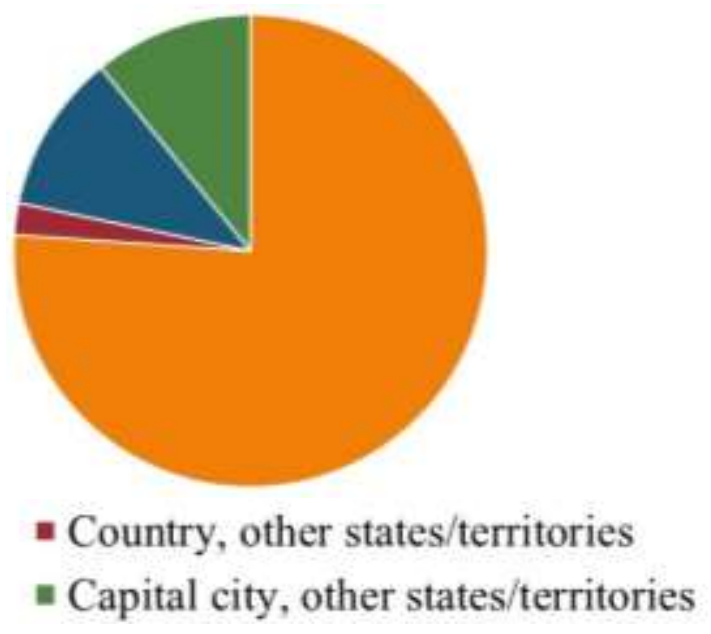

b. Location of current employment

\section{Residential colleges}

The majority of respondents lived on-campus for all or part of their undergraduate study at UNE (80\%), and of these, over $90 \%$ agreed that living in college benefitted their course progression. Career development through lifelong connections and networks was a key response regarding the benefits of living in the residential colleges. Quotes from three respondents summarise the benefits of the college experience for their career through "Great networking" with peers "who would become contacts within industry", and from the college alumni network who "helped me progress in my career." Other benefits of college life are similar to those outlined by students in the 1970s (Watkins, 1977) including additional academic and pastoral support; structured peer group study opportunities; support from older students; commonality with peers (similar backgrounds); feeling of belonging and sense of community; and sporting community.

\section{Careers page}

From the information provided by the graduates regarding their careers the authors of this paper built an informative evidence based website. The website aimed to better inform prospective students which course best suited their career aspirations, and can be approached from either the 'careers page' or the 'agricultural courses page' of the discipline website. From the 'careers page', users select the career they are interested in such as 'agricultural research', then information about that career is given and which course they should study (www.une.edu.au/about-une/faculty-of-science-agriculture-business-and-law/school-of-

environmental-and-rural-science/careers/agricultural-careers). Alternatively from the 'agriculture courses page', prospective students can select the course they are interested in and 
it links to prospective careers (www.une.edu.au/ers-courses). For example, selecting the Rural Science course, information from the graduate survey listing all the agricultural careers graduates have entered using their degree, and in some cases suggestions of postgraduate studies are given.

\section{Conclusion}

The majority of graduates of UNE agricultural courses, from 2005-2016, found the Australian Threshold Learning Outcomes (TLOs) for Agriculture relevant for their career pathways. Employment rates for agriculture graduates where high during this period with diverse employment opportunities allowing flexibility in occupation. The foundation in both science and vocational training provided transferable knowledge and skills for graduates at both initial and further stages of employment in both agricultural and other industries. For many graduates, college life was important to successful employment post-graduation, for developing positive connections in learning and social support networks, and links to employment opportunities. The majority of graduates were employed in rural and regional areas, with many returning to NSW after initial employment. More than half of undergraduates continued with further study after their first position, to further their skill set, improve career opportunities and increase pay bracket. A key quote from a graduate encapsulates this: "Rural science gave me a broad understanding of all agricultural disciplines and relevance to industry. More than anything it taught me to ask the right questions and how to seek answers." A general consensus from graduates was that having a degree with discipline, professional and vocational outcomes demonstrates to a potential employer dedication to a culture of lifelong learning and time management: "It is not so much your in depth knowledge of the course content, but it is being able to demonstrate that you are keen and willing to learn".

\section{References}

Australian Bureau of Statistics (2013). Australian and New Zealand Standard Classification of Occupations. Cat no. 1220.0. Canberra, Australian Capital Territory: Australian Bureau of Statistics.

Beer, D. R. (1995). 'Friendship is as traditional at UNE as wisteria and roses': Student attitudes and student life at the University of New England, 1946/1964. Journal of the Royal Australian Historical Society, 81(2), 213-230.

Botwright Acuña, T.L., Able, A.J., Kelder, J., Bobbi, P., Guisard, Y., Bellotti, W., McDonald, G., Doyle, R., Wormell, P., \& Meinke, H. (2014). Learning and Teaching Academic Standards Statement for Agriculture. Sydney, Australia: Office for Learning and Teaching.

GradStats (2018). Employment and salary outcomes of higher education graduates from 2017. Retrieved December 20, 2018, from http://www.graduatecareers.com.au/wp-content/uploads/2018/01/GradStats-20173.pdf

Harrison, S., Villano, R., Lynch, G., \& Chen, G. (2015). Likelihood analysis of student enrolment outcomes using learning environment variables: A case study approach. In Proceedings of the Fifth International Conference on Learning Analytics and Knowledge, (pp. 141-145). Poughkeepsie, NY, USA: Association for Computing Machinery.

Lazenby, A. (2011). Leadership, management and training in grassland research: Some personal experiences and impressions. Pastos, 32(1), 5-46.

Office of the Chief Scientist (2016). Australia's STEM Workforce: Science, Technology, Engineering \& Mathematics. Canberra: Australian Government.

Palmer, S., Campbell, M., Johnson, E., \& West, J. (2018). Occupational outcomes for Bachelor of Science graduates in Australia and implications for undergraduate science curricula. Research in Science Education, 48, 989-1006.

Pratley, J. (2008). Workforce planning in agriculture: Agricultural education and capacity building at the crossroads. Farm Policy Journal, 5(3), 27-41.

Pratley, J. (2015). Agricultural education and damn stats II: Graduate employment and salaries. Agricultural Science, 27(1), 51. 
International Journal of Innovation in Science and Mathematics Education, 27(4), 2-13, 2019

Quality Indicators for Learning and Teaching (2018). 2018 Graduate Outcomes Survey - Longitudinal (GOS-L), Medium-term graduate outcomes October 2018. Retrieved December 7, 2018, from https://www.qilt.edu.au/about-this-site/graduate-employment

Quality Indicators for Learning and Teaching (2019). 2018 Graduate Outcomes Survey National Report January 2019. Retrieved January 7, 2019, from https://www.qilt.edu.au/about-this-site/graduate-employment

UNE (2013). University of New England Annual Report. UNE: Armidale. https://www.une.edu.au/_data/assets/pdf_file/0007/68650/2013-Narrative.pdf

Watkins, D. (1977). Student withdrawal at the University of New England. Australian Journal of Social Issues, 12(2), 140-151. 